\title{
Nosocomial Infection
}

National Cancer Institute

\section{Source}

National Cancer Institute. Nosocomial Infection. NCI Thesaurus. Code C115164.

An infection acquired in a hospital or other healthcare setting. 